\title{
María Zambrano y el legado anti-erudito de Unamuno: (dis)continuidades del Quijote como Esfinge
}

Recibido: 24/2/2021. Aceptado: 11/3/2021.

\begin{abstract}
Resumen
Frente a la tradición erudita de finales del siglo XIX, las lecturas simbólicas del Quijote proyectaron la idea del libro como cifra de una genuina filosofía española. El aporte de Unamuno al respecto no solo fue central para la reivindicación de un modo anti-racionalista de valoración del canon, sino que además legó al encuadre de sus sucesores un entramado metafórico capaz de relacionar la novela con España en sí y con el mito de la Esfinge. En esta línea puede arriesgarse que Zambrano recogió esa vinculación entre el libro, la nación y el mito, y propuso una filosofía personal superadora.
\end{abstract}

Palabras clave: Unamuno; Zambrano; metáfora; Esfinge; Quijote.

María Zambrano and Unamuno's anti-scholarly legacy: (dis) continuities of Don Quixote as Sphinx

\begin{abstract}
Against the scholarly tradition of the late nineteenth century, the symbolic readings of Don Quijote show the idea of that book as a figure of a genuine Spanish philosophy. Unamuno's contribution was not only central to the vindication of an anti-rationalist way of valuing the canon, but also gave his successors a metaphorical framework capable of relating the novel to Spain itself and to the myth of the Sphinx. In this way, Zambrano picked up that link between the book, the nation and the myth, and proposed an overcoming personal philosophy.
\end{abstract}

Keywords: Unamuno; Zambrano; metaphor; Sphinx; Quijote. 


\section{El enigma de España y una metáfora múltiple}

En el estudio prologal a su edición del Unamuno de María Zambrano, Mercedes Gómez Blesa señala que la escritora guarda familiaridad con el autor objeto de su estudio por un modo específico del filosofar ligado al discurrir por metáforas:

Ambos autores reivindican la capacidad cognoscitiva de la metáfora como forma originaria con la que el hombre percibe el entramado de relaciones de lo real, frente al hieratismo del concepto (en Zambrano, 2017: Introducción, s/p).

Esta opción de la metáfora por sobre el concepto constituye la fase retórica de un enfrentamiento sostenido en el tiempo, desde fines del siglo XIX, entre dos interpretaciones diversas del saber. Por un lado, el apogeo decimonónico del positivismo finisecular había erigido a la erudición española como instancia fundacional del capital literario de la nación. En este sentido, el historicismo erudito se proyectó como custodia de los documentos que permitían explicar el ser mismo de la identidad cultural de una historia cuyo declive imperial necesitaba de cierta redención simbólica. Se trató de una lectura academicista, signada por un rigor documental abocado sobre todo a la delimitación de un canon y a la confección de su catálogo bibliográfico. Por otro lado, para el mismo momento emerge en España cierta línea de crítica simbólica, empeñada en comprender la literatura canónica como nodo metafórico del cual se irradian las diferentes imágenes constitutivas de la genuina filosofía nacional. Esta segunda forma de percibir el saber trascendente, extraído de la interpretación crítica de la literatura, contuvo postulados como los de Miguel de Unamuno en torno al Quijote. Lo interesante al respecto es la persistencia a lo largo de los años de ese entramado metafórico unamuniano en sucesores como María Zambrano. La Esfinge, en ese sentido, reaparece en ambos autores como mito simbólico capaz de superponerse no sólo con el libro cervantino sino también con la patria misma, referentes enigmáticos donde vendría a cifrarse la voluntad perdida del ser español.

En este sentido tanto don Quijote como la Esfinge parecen adquirir rasgos simbólicos intercambiables, propios de lo que Paul Ricoeur dio en llamar metáfora viva. Al respecto, Ricoeur sostiene que la enunciación metafórica opera sobre dos campos de referencia a la vez: "Esta dualidad explica la articulación de dos niveles de significación en el símbolo" (1977: 446). En primer lugar la significación relativa al campo de referencia conocido, "es decir al campo de las entidades a las que pueden ser atribuidos los predicados, considerados en su significación establecida" (446). Y en segunda instancia, la significación

que se trata de hacer aparecer, [la cual] es relativa a un campo de referencia para el que no hay caracterización directa, para el cual, en consecuencia, no se puede proceder a una descripción identificante por medio de predicados apropiados (446).

Según Ricoeur, la intención semántica que anima a la enunciación metafórica es "poner en relación estas dos energías" (446) que vuelven a escenificar -a nivel retórico- dos fuerzas antagónicas en torno a lo real. "Si la imaginatio es el reino de lo semejante, la intellectio es el reino de los mismo", señala Ricoeur (448). Tanto la Esfinge, entonces, como su símbolo análogo de don Quijote, reaparecen una y otra vez en las estrategias anti-eruditas que intentan "nombrar" de manera oblicua la esencia hispana debilitada. La manipulación de estas metáforas actualiza el vínculo exegético entre literatura y filosofía durante la primera mitad del siglo XX. La continuidad al respecto entre Unamuno y Zambrano es uno de los temas que se desarrollarán en este trabajo. Porque la enunciación común de estas metáforas no sólo los emparenta en torno a cierto anti-racionalismo de la época, sino que los ubica a ambos en las coordenadas de la metáfora viva tal como la explica Ricoeur: 
la metáfora es viva porque inscribe el impulso de la imaginación en un "pensar más" a nivel del concepto. Esta lucha por el "pensar más", bajo la conducción del "principio vivificante" es el "alma” de la interpretación (452).

\section{El nombre o la muerte: de quijotes, esfinges y eruditos}

Inédito por más de seis décadas, el Unamuno de Zambrano vino finalmente a echar luz no sólo sobre la obra del escritor vasco, sino también -y esto resulta fundamental- sobre la manera en que la filosofía de su autora se dio a contender con el legado literario del referente abordado. Es inevitable, en este sentido, focalizar en el interés que implica dentro del libro de Zambrano la doble tragedia de Unamuno, entre lo temporal y lo eterno. A su juicio, Unamuno se debatió entre el amor a "dejar consagrado su nombre" (2017: cap. IV, s/p) y, al mismo tiempo, su inevitable preocupación por lo trascendente. Redactado entre 1940 y 1942, el estudio de Zambrano sobre Unamuno resulta de una riqueza multifacética, pero nunca resigna su énfasis en aquella contradicción trágica que identifica como individual y que describe a la vez como coincidente con la tragedia macro del contexto social que circundaba a Unamuno. Esta idea de la tragedia doble, de la envidia y de la muerte, se entronca según Zambrano con la mayúscula "tragedia ante los límites que cercan la vida y la hacen enigmática" (cap. IV, s/p). En España, ese "enigma" de lo vital logró hallar, desde fines del siglo XIX, ciertos cauces simbólicos capaces de irradiar la complejidad de sus sentidos. Y ese es de algún modo el marco donde la figura de don Quijote ingresa de plano como catalizador de versiones de lo nacional, poniendo a prueba el modo interpretativo del canon español, entre las demandas del ámbito erudito -ligado a sublimar bibliográficamente el evidente declive finisecular-, y las exigencias de lecturas filosóficas como la de Unamuno o, posteriormente, la de la propia Zambrano. Como ocurre con la tensión entre Alonso Quijano y don Quijote, el campo intelectual de principios de siglo XX parece haberse debatido también entre lo terrenal y lo trascendente: el gran drama de la conciencia que exponía el trágico declive español, encontraba en don Quijote una condensación de sentidos capaz de vehiculizar los debates sobre la filosofía deseable para la nación. Esto parece descubrir Zambrano en su temprano estudio sobre Unamuno, cuando entiende que don Quijote remeda de cierto modo la propia tensión íntima del autor que toma por objeto. Don Quijote pasa a ser, en esta línea, un avatar de la Esfinge, aquel monstruo mítico cuya recurrencia plagó primero los postulados anti-eruditos de Unamuno y también, con el tiempo, el discurso anti-racionalista de Zambrano. La analogía entre don Quijote y la Esfinge viene a plasmarse de forma evidente en los planteos de ambos autores, y expone con claridad la deuda sostenida por el pensamiento español con respecto al enigma de lo vital, entendido desde el período finisecular como disyuntiva trágica entre la muerte y la fama.

A partir de Unamuno, Zambrano comprendió que el último tramo del siglo XIX estuvo signado por la contradicción que imponían dos variables: por un lado, la progresiva racionalización positivista y la instauración definitiva de la conciencia como punto de partida de todo postulado filosófico; por otra parte, la búsqueda de trascendencia personal, ya sea por la creencia metafísica o por la fama. Aparece así una lucha originaria entre la razón y la afanosa necesidad de una supervivencia que, lejos de entregarse a la especulación ultraterrena, suele caer según Zambrano en la vanidad inconsciente:

Una de las consecuencias de los caracteres de esta edad de la conciencia es, sin duda, esta inmensa profusión de bustos, lápidas, nomenclaturas de plazas y calles, y demás formas de la fama. Idolatría del nombre en la época del furor iconoclasta (2017: cap. I, s/p). 
El entorno iniciático de Unamuno se le presenta claramente a Zambrano como momento propicio para su emergente carácter polemista, llegando incluso a producir en él "un juego rayano en ocasiones a la irresponsabilidad de sus paradojas, de sus opiniones en contra de su pensar y creer en contra de la corriente" (cap. I, $\mathrm{s} / \mathrm{p}$ ). Es en prosecución de este rol que Zambrano puede identificarlo una y otra vez con el carácter quijotesco, hasta definirlo como "un hidalgo rebelde a la civilización cortesana del XIX que en aquellos años, a partir de la Restauración, entraba en su apogeo" (cap. I, s/p). Esa instancia restauradora es entonces la que estimula de forma directa el rol unamuniano del que batalla con lo dado y que a través de su constante intervención agónica no sólo consigue sostenerse en el tiempo, sino también hacer que su nombre permanezca:

Y es que esta idolatría del nombre individual reproduce probablemente cierta piedad sencilla, cierta forma de culto y adoración inmediata que en otra época se dedicaba a los santos, a los héroes de leyenda. Es la mitología de una edad sin ella, y también la consagración de los laicos; piedad de la fama extendida sobre la desolación de un mundo de conciencias solitarias (cap. I, s/p).

Esa piedad de la fama nominal y su culto correspondiente a santos laicos eclosiona en el contexto unamuniano por muchos motivos: entre ellos por el valor inocultable que el campo erudito había proyectado sobre sus propios agentes como héroes aislados, consagrados a la reivindicación del canon, sacrificados en aras del capital simbólico de la nación. No resulta azaroso evocar en esta línea la figura de Menéndez y Pelayo, cuyo nombre no solamente logra aglutinar en su tiempo las garantías de un saber totalizante exigido por la historia a restaurar, sino que además sobrevive como esencia inatacable del erudito santificado en los términos propios que Zambrano describe. De hecho, no resulta ocioso señalar que aquello que Zambrano anticipó a principios de la década del '40, se replicaría incluso años después, en el curioso derrotero post mortem del santanderino. Vale recordar que el 26 de agosto de 1956, el franquismo procedería a la capitalización simbólica de su figura, trasladando los restos mortales de Menéndez y Pelayo (fallecido hacía más de cuatro décadas), desde el cementerio de Ciriego a la catedral de Santander, donde el escultor Victorio Macho (vuelto de su exilio reciente) había construido el monumental sepulcro del escritor. En el brazo izquierdo del crucero de la catedral, Macho dispuso en roca el monumento funerario en el que yace la figura desfallecida de Menéndez y Pelayo, vestido con sayal de fraile (tal como fue amortajado su cadáver). Recostado el cuerpo de piedra sobre el túmulo fúnebre, su cabeza descansa sobre dos abultados volúmenes. Su mano derecha sostiene lánguidamente una pluma que parece estar por caer, y su mano izquierda oprime con su peso una cruz sobre otro libro abierto que a su vez reposa sobre su pecho. La saturación libresca del conjunto parece referir al contexto descripto por Zambrano años antes: un momento último de ese lector monumental, heroico, vencido únicamente por el deceso natural en medio de la íntima batalla por dar lectura a una especie de Biblioteca absoluta de la patria, empresa santificada que tal como testimonia la propia escultura, viene a otorgarle su redentora fama. Al pie del monumento puede leerse una leyenda que le fuera atribuida a Menéndez y Pelayo y que pareciera redondear su representación icónica de lector fundacional: "¿Qué lástima tener que morir cuando me quedaba tanto por leer!".

El destino póstumo pelayano, capitalizado en buena parte por las estrategias ideológicas del franquismo de posguerra, confirma el acierto de Zambrano sobre la descripción del contexto originario de Unamuno como una encrucijada quijotesca entre las diversas formas de la fama. Y más aún cuando el azar consigue cifrar de modo retrospectivo el detalle significativo de que el propio Victorio Macho no sólo habría de esculpir la sepultura oficial del erudito santanderino, sino que había realizado ya, a fines de 1929, el busto más emblemático de quien iba a ser el intelectual objeto 
del estudio zambraniano. Como ocurriría luego con la de su maestro, la escultura de Unamuno exhibe en su pecho una cruz que al decir del propio escultor habría marcado el modelo mismo durante sus sesiones en el destierro de Hendaya.

No se equivoca Zambrano al identificar el problema de la trascendencia y las múltiples formas de la fama con relación al contexto de su autor estudiado, y parece acertar también en vincularlo con el dilema quijotesco y con el carácter metafórico de la Esfinge. No por nada fue la Esfinge, desde su tradición clásica, figura pionera de carácter fúnebre que recién luego, en su devenir a posteriori, adquirió relevancia como guardiana del enigma, del saber cifrado. No parece casual que sea la Esfinge mención recurrente en las contiendas sobre el saber dentro de este marco decimonónico poblado de monumentos que ligaban por igual lo tanático y la esquiva trascendencia, por la fama o por la fe. ${ }^{1}$ Describe Unamuno a la Esfinge con su emisión de un castigo doble: por un lado la condena del sujeto que no puede responder sus interrogantes; por otro, la que marca el destino trágico del espacio erudito cuya mirada "positivista" se había dilatado en la observación de lo nimio. Tal como explicaría en su diatriba titulada "Eruditos, ja la Esfinge!", de 1918:

Ahora, la dificultad para estudiar esto estriba en que la Esfinge no se deja analizar tan aínas, y sí devora al que no adivina sus enigmas, y el tormento de ser devorado por la Esfinge, si es tal tormento, se acaba pronto; en cambio, al que, esquivando su mirada y sus preguntas, se le va de soslayo a ver si logra sacarle unas gotitas de sangre para analizarla o mirarle el pezón de una ubre al miscroscopio -la Esfinge es hembra-, a ése le patea y le magulla, que es mucho peor que devorarle. Al fin, el devorado por la Esfinge acaba por convertirse en carne y sangre de la Esfinge misma, se hace esfíngico o querúbico, mientras que el del microscopio perece entre las deyecciones de ella (1952: 805).

Unamuno establece, acorde a su "sentimiento trágico de la vida", la posibilidad de un saber doble ante la Esfinge y, por lo tanto, de una doble muerte. La primera, cuyo tormento incluso se relativiza, consiste en la propia noción de agonía, de lucha con la duda motora que torna al sujeto mismo en "esfíngico", en víctima del enigma y a su vez en el enigma mismo a ser asediado. Una paradoja vital cuya contradicción dota de existencia quijotesca al sujeto y a su búsqueda, la cual pasa de ser científica a ser ontológica. Esta muerte dista mucho de la opción segunda, aquella definitiva, tocante a la erudición decimonónica cuyos rasgos racionalistas, superficiales y ocular-céntricos terminarían por someterla a un declive aséptico, clasificador, empeñado siempre en evadir la verdadera mirada de la Esfinge.

Zambrano presenta coincidencias con la articulación metafórica de la Esfinge según este sentido unamuniano, por medio del cual se ataca el adormecimiento racionalista de Europa. Pero al mismo tiempo, y tal como ya ha explicado David Soto Carrasco, reivindica también dentro de su propia obra "la existencia de cierto esencialismo hispano" (2013: 213) al cual habría recogido de su atenta lectura tanto de Unamuno como también de su apreciación de ese erudito modélico que había sido Menéndez y Pelayo. De ambas canteras habría extraído Zambrano "una razón poética hispana, capaz de proyectar y enfrentar una determinada España frente a Europa” (213).

1 En su exhaustivo panorama sobre el simbolismo de la Esfinge, Cristóbal Macías Villalobos señala que uno de los ámbitos del mundo griego donde la esfinge parece haber desempeñado un papel previo más relevante es el funerario: "En efecto, desde la época micénica, la esfinge está asociada a los sepulcros. Colocada sobre un pilar o sobre la propia tumba, actuaba a la vez tanto como el demon que arrebata al muerto del mundo de los vivos y como la compañera que le garantiza la subsistencia en el más allá” (2012: 264). No parece casual entonces la recurrente apelación al mito durante la contienda intelectual sobre la erudición, ese debate que congregó tantas veces, al filo del siglo XIX, los temas del saber, de la trascendencia, de lo monumental y lo funerario. 
En su propio estudio sobre Unamuno, Zambrano sostiene que el contexto finisecular del XIX mostró la parálisis del pensamiento español, su inhibición frente a los grandes sistemas y a la eficacia del racionalismo. En medio de ese panorama, opina que Menéndez y Pelayo fue una excepción: "su obra es conocimiento", afirma Zambrano, "conocimiento de la historia íntima de España, visión de su sustancia, y como nadie hasta el presente ha derramado transparencia en nuestro confuso pasado" (2017: cap. I, s/p). Esta obra, que es calificada como "conocimiento", claramente destaca sobre el fondo conflictivo de la filosofía unamuniana que Zambrano intenta a la vez desentrañar. Nuevamente el derrotero de su análisis proyecta a Unamuno como escudriñador del sentido vital de España, un enigma que se vincula metafóricamente con el Quijote y que, por otra parte, reconduce su figura al mito de la Esfinge. En esta apreciación suya de Unamuno, Zambrano llega a afirmar: "Unamuno, en verdad, ha sido el ídolo de esta resurrección de España, la ha despertado, infatigablemente, usando hasta de la violencia" (cap. I, s/p). ¿Cuál ha sido la gran revelación de Unamuno?, se pregunta Zambrano, y esboza seguidamente: “¿Ha sido lo genuinamente español, es decir, el misterio último, el que late y se vela bajo el libro genial e irónico, bajo el espejo inasible del Quijote?" (cap. I, s/p). Más allá del esencialismo que Zambrano identifica en Unamuno, y de su crítica al autor por haber revelado sólo lo español que parecía necesario a la cultura europea, más allá de sus diferencias con los modos amplificados de la época y con la extrema contradicción unamuniana, Zambrano logra destacar los lazos de Unamuno con el Quijote así como también su rol "esfíngico" despertando la conciencia de su tiempo. Tanto es así que esa descripción de 1940 donde se designa a Unamuno como aquel que fue capaz de provocar el "despertar" de España, resuena todavía en 1958 cuando Zambrano evoca el propio mito de la Esfinge en Persona y democracia. Menciona allí que la historia ha llegado a ser, para los tiempos modernos de España, una pesadilla, un monstruo que en cierto instante fugaz puede convertirse en Esfinge. Esa Esfinge se alza en el desierto, porque no se ha dado la condición aún del despertar consciente de los sujetos capaces de vivir el tiempo en que puedan ejercer su libertad. "No transcurrirá mientras no lleguemos a entrever la realidad que acecha y gime dentro de la Esfinge", señala Zambrano, la cual "es siempre la misma: el hombre" (1988: 13). En su opinión el hombre escondido en la Esfinge es, al mismo tiempo, un condenado por el pasado y un desconocido que clama por ser. Enfrentarse a la Esfinge implica oír dentro de ella el gemido contrariado de la verdad del hombre, y en la perplejidad de ese trance nacería un enigma que abre ante el sujeto la conciencia histórica. Lejos del corte revolucionario, y en franca coincidencia con la descripción del rol unamuniano, el hombre frente a la Esfinge augura un porvenir que no repita el pasado: su conciencia accede de ese modo a la historia verdadera, nace gracias a la perplejidad y abandona la mascarada cíclica de la historia trágica. ${ }^{2}$

El carácter "esfíngico" de Unamuno parece referir según Zambrano a un sostenido modo de aprehender la esencialidad hispana en su tensión con la historia como tragedia. Y uno de los lugares donde mejor puede identificarse el legado unamuniano, es en el modo en que Zambrano intentó abordar y leer ese espejo inasible que fue el Quijote, avatar literario de la metáfora de la Esfinge tan recurrente en la contienda con el racionalismo hegemónico. Tal como explica Soto Carrasco

\footnotetext{
2 Al respecto explica Zambrano: “La historia trágica se mueve a través de personajes que son máscaras, que han de aceptar la máscara para actuar en ella como hacían los actores en la tragedia poética. El espectáculo del mundo en estos últimos tiempos deja ver, por la sola visión de máscaras que no necesitan ser nombradas, la textura extremadamente trágica de nuestra época. Estamos, sin duda, en el dintel, límite más allá del cual la tragedia no puede mantenerse. La historia ha de dejar de ser representación, figuración hecha por máscaras, para ir entrando en una fase humana, en la fase de la historia hecha tan sólo por necesidad, sin ídolo y sin víctima, según el ritmo de la respiración" (Zambrano, 1988: 44). Según Zambrano, el instante del despertar -ese que Unamuno habría sabido provocar según su descripción en el libro donde lo retrata- es "el instante de la perplejidad que antecede a la conciencia y la obliga a nacer" (13). Hacer nacer la conciencia sería, en este sentido, despertar a una historia que supere la tragedia, obligar a mirar ojos a ojos a la Esfinge, objetivo cercano al mandato unamuniano que la erudición tradicionalmente había desacatado.
} 
El escritor vasco combate, según Zambrano, en el positivismo, en el pragmatismo, lo que combate toda filosofía, algo que él no especifica y que es lo que está en el fondo de ella, más aún en su comienzo en Grecia: la resignación. Su "guía”, su Vida de Don Quijote y Sancho, no sería más que un intento de rescatar la verdadera vida (2013: 234).

Así, es inevitable evocar los postulados de Ricoeur al pensar en este tema de lo antagónico de la filosofía como algo esquivo y difícil de denominar, algo que exige ser enfrentado por medio de metáforas vivas y liberadoras. Una vez más, entonces, puede entenderse a Unamuno como artífice del pensamiento en torno al enigma de lo vital, a ese dilema que eligió ver cifrado en don Quijote, representante del hombre entero, de aquel que se veía preso de la Esfinge y esfíngico él mismo, reuniendo en sí mismo al Quijano terrenal y también a Dulcinea, ansia de inmortalidad, "voluntad del mejor yo a través de la historia" (Soto Carrasco, 2013: 234). Frente a la resignación objetivista del cientificismo erudito, Unamuno emerge a ojos de Zambrano como quien reivindica la veta anti-racionalista de la filosofía intrahistórica española. ${ }^{3}$ Es por esto que habría que relativizar su cercanía equidistante con Menéndez y Pelayo, y con Unamuno. Es correcto que para Zambrano y para esos referentes, España no requería una europeización sino una aceptación de su unicidad, del empeño de su pueblo por seguir "guiándose y soñándose en su interior a sí mismo, más allá de las apuestas imperiales que incendiaban Europa" (232). Sin embargo, también es cierto que Zambrano encontraba más familiaridad con Unamuno en el amparo de una "renuncia a toda idea de imperio" (229) que en las exigencias redentoras del historicismo finisecular decimonónico. Su referencia recurrente al Quijote en el libro sobre Unamuno da cuenta de esto. Y en este sentido, y en términos del análisis que ha hecho al respecto Anthony Close (2005), Zambrano emerge como una lectora -en general, pero del Quijote en particular- que entronca con la tradición anti-erudita inaugurada por Unamuno y por Ortega y Gasset. ${ }^{4}$ Es decir, se vincula con el legado de una lectura simbólica, heredera del romanticismo, capaz de apreciar la literatura ya no como documento del capital bibliográfico de la nación, sino como núcleo metafórico de la genuina filosofía española. Y es por esto que su atención específica al modo en que Unamuno lee el Quijote la habilita a proyectar su propia hipótesis superadora tanto de la interpretación del escritor vasco, como del mandato erudito que lo había precedido.

A partir de su lectura, Zambrano describe a Unamuno como aquel que se sintió llamado a brindar la revelación de la esencia filosófica de España y que lo hizo a través de un argumento y de una figura que halló en el Quijote. Don Quijote vendría a ser la metáfora de una fe que crea las propias imágenes que adora para persistir en su voluntad de

3 Unamuno expresó claramente la identificación entre lo erudito y el racionalismo dominante, y lo hizo incluso en una detracción directa contra su maestro Menéndez y Pelayo donde describe esa "resignación" combatida por él. Así escribió en su artículo "Don Marcelino y la Esfinge”, de 1932: “¿Y él, D. Marcelino? Él, el periodista que compaginaba en robustos volúmenes hojas volantes, pensador -o investigador más bien- sincrético y errabundo más que filósofo. Benedetto Croce ha visto muy bien que le faltó filosofía. Y yo, que fui su discípulo directo -y hasta oficial-, que le quería y le admiraba, tengo motivos para creer que la honda filosofía, la contemplación del misterio del destino humano, le amedrentó y que buscó en la erudita investigación, un anestésico, un nepente, que le distrajera. No se atrevió a mirarle ojos a ojos humanos a la Esfinge, y se puso a examinarle las garras leoninas y las alas aguileñas, hasta contarle las cerdas de la cola bovina con que se sacude las moscas de Belzebú. Le aterraba el misterio" (Unamuno, 1952: 403).

${ }_{4} \mathrm{Al}$ respecto conviene destacar la descripción de las variantes lectoras del Quijote que precedieron a Zambrano: "Por un lado estaban los que, como Federico Castro y Unamuno se decantaban por una interpretación simbólica del Quijote al tiempo que postulaban que el autor no fue consciente (o lo fue en poco grado) de tal significado profundo. Luego estaban los representantes tanto del sentido común escéptico como de la erudición más imponente y prestigiosa -Juan Valera, Menéndez Pelayo, Morel Fatio, Rodríguez Marín- quienes, de acuerdo con una tendencia tradicional desde los tiempos de Clemencín, consideraban que Cervantes fue un autor inocente, falto de capacidad crítica, carente de originalidad en sus opiniones, negligente en el estilo y la construcción de la trama y dado a contradecirse a sí mismo en cuestiones abstractas, como las relativas a la teoría literaria. Esta opinión surgió en gran medida como reacción a los elogios desmedidos que otras dos clases de críticos [...] habían vertido respecto de las virtudes intelectuales del autor alcalaíno. Se trata, por un lado, de la que podemos llamar "escuela panegirista"; por otro, de la "esotérica" (Close, 2005: 122). Sobre la inscripción de Unamuno y de Zambrano en este panorama también resulta relevante el estudio de Trapanese (2010). 
existencia. Don Quijote representa para Unamuno, según Zambrano, esa misma tragedia de lo español consistente en ser uno, en ser quien se es y a la vez portar el deseo de vivir derramado en otros. Puede arriesgarse entonces que en esta línea anti-erudita (iniciada por Unamuno y proseguida por la misma Zambrano), el Quijote termina por constituirse como libro-esfinge, frente al cual es el intelectual quien debe desentrañar el enigma vital que el historicismo legitimado había evitado. Y esto puede darse por la identificación metafórica que opera la lectura unamuniana entre don Quijote y España; identificación que Zambrano viene luego a confirmar lateralmente, al sumar en su lectura de Unamuno la analogía latente entre España y la Esfinge:

Se ha dicho de España "que ha querido demasiado". Hemos querido a lo largo de la historia. Mas nuestro querer ha permanecido misterioso para nosotros los españoles, tanto que ha hecho de España un pueblo-esfinge. La esfinge necesita ser liberada de su figura, ser rescatada, ser incorporada por la revelación de su enigma al mundo de lo humano (2017: cap. V, s/p).

Zambrano lee Vida de don Quijote y Sancho dentro del género de las guías, presentes en el decurso de la cultura española desde Miguel de Molinos y Fray Luis de Granada. Allí, según afirma, Unamuno muestra su afán de apoderarse de don Quijote convirtiéndolo en personaje trágico: "Sentía al personaje genial en tragedia y no en novela, como lo sintió Cervantes con su ironía” (2017: cap. V, s/p). Y en Vida..., entonces, Unamuno construye según Zambrano un pensamiento trágico que viene a saldar la tragedia poética que el autor no logró realizar jamás. Esa guía del pensar trágico busca "conducir a un pueblo ante el laberinto de su destino" (cap. V, s/p), ya que Unamuno "quiere, mediante Don Quijote, revelar el destino de España" (cap. V, s/p). No puede ser más explícito el circuito metafórico que cierra aquí Zambrano estrechando distancias en la forja unamuniana de una sola identidad entre el personaje y España, núcleos análogos de esa gran Esfinge que vuelve a mencionarse en el Unamuno como parte de una tríada simbólica recurrente entre libro, nación y mito:

En la Historia Universal ha habido algunos pueblos-esfinge, pero, al pertenecer a la Antigüedad, su enigma se confunde con el que trae la distancia en el tiempo. España presenta el insólito caso de un pueblo-esfinge para los mismos contemporáneos, que han perdido su secreto, es decir, la continuidad de la inspiración histórica, el secreto último de su voluntad (cap. V, s/p).

Aquel volumen de Unamuno sobre el Quijote que Jorge Luis Borges calificaría a fines de los '60 como "irrelevante" (2001: 114), Zambrano, en cambio, eligió verlo dos décadas antes como el eslabón último de las guías espirituales, de esos libros capaces de orientar al sujeto español en el desciframiento de su enigma espiritual. La cadena metafórica que la lectura de Zambrano viene a clausurar en su planteo es la de identificar Quijote / España / Esfinge como punto de referencia uno y múltiple hacia donde orientar la búsqueda de la voluntad perdida del español. La superposición metafórica del libro, de la nación y del mito parece constituir la principal estrategia interpretativa que la lectura de Unamuno legó a María Zambrano, dotándola de un "discurrir por metáforas" que le permitió distanciarse de los criterios racionalistas con que la erudición había valorado la literatura cervantina, y permitiéndole abrir camino para su propia apreciación simbólica del Quijote.

\section{Zambrano frente al Quijote: (dis)continuidades unamunianas}

Reiteradas veces se ha señalado que la lectura que Zambrano hace del Quijote resulta ante todo de una síntesis lograda a partir de dos interpretaciones previas: por un lado, la de Ortega y Gasset en Meditaciones del Quijote; por otro, la de Unamuno en 
su "guía" al respecto. Para Zambrano estas dos versiones se oponen en cuanto a sus estrategias para el salvataje de don Quijote y, por lo tanto, de España. En su parecer, Unamuno propone acercarse al libro con la voluntad de descifrar un enigma, de identificarse con el protagonista y así liberarlo de la ambigüedad de la novela, consagrándolo a su vez como reflejo del lector y como sujeto trágico, eterno. Ortega, en cambio, no considera al personaje sino al libro, y es al autor del libro, a Cervantes, a quien quiere descifrar. Entre ellos también reaparece la polémica sobre dos modos del conocer: mientras uno busca resolver la valoración del libro por medio de los alcances trascendentes de la metaficción, el otro intenta pensarlo acercándose a la mirada del autor y a las circunstancias de donde emerge esa mirada. Entre ambas posturas, Zambrano termina por augurar la necesidad de unir filosofía y poesía, lo cual puede entenderse como clave de su propia razón poética, alentando una superación interpretativa de las modalidades divergentes de sus antecesores. ${ }^{5} \mathrm{Y}$ sin embargo, y a pesar de su equivalente atención a ambas posiciones, a lo largo de los varios años en que ensaya su lectura del Quijote no parece difícil considerar una preferencia recurrente por las hipótesis unamunianas. ${ }^{6}$ Tal como ha notado Juana Sánchez-Gey Venegas: "La filosofía de Unamuno, como la de Zambrano, es una filosofía de salvación surgida en tiempo de crisis, una filosofía personal que propone la piedad como conocimiento" (2002: 203). Es por esto que Zambrano vincula la Vida de don Quijote y Sancho con el género de las "guías espirituales" y define a Unamuno como un místico sin método o, más bien, como un poeta. ${ }^{7}$ Esa figura de Unamuno como proveedor de un nuevo "conocer" ligado a lo vital y a la poesía, como mediador entre el símbolo y el pueblo, se contrapone en su análisis con la figura de Ortega y su incidencia acotada al círculo exclusivo de sus discípulos. Unamuno viene a reunir las condiciones del filósofo-poeta, capaz de concentrar en sí mismo la virtud de ese nuevo tipo de razón poética que Zambrano promovía ya y que presentaba familiaridades con conceptos que ella misma identificaba en su análisis de Del sentimiento trágico de la vida. Tal como señala Carmine Luigi Ferraro, "en la concepción de la filosofía como poesía, de la palabra como poiesis se encuentra la influencia que don Miguel tiene en la reflexión de María Zambrano" (1999: 23). La poiesis implicada en la palabra poética -entendida como nueva filosofía no sólo del crear, sino del conocer- actualiza el valor de ciertas metáforas (de don Quijote a la Esfinge) en la continuidad del intento por descifrar el enigma vital de España.

La lectura que Zambrano hace del Quijote, entonces, debe mucho a ciertas resonancias previas. Ya en 1938 publica su artículo sobre "La Reforma del Entendimiento español" y expresa allí una idea de neta raigambre unamuniana. A contrapelo de su continente, España habría encontrado su genuina filosofía lejos del racionalismo hegemónico y de las teorías sistemáticas de la cultura europea:

5 Esta categoría troncal de razón poética resulta de suma complejidad en la obra de Zambrano. Su hipótesis es que el excesivo racionalismo del siglo XX produjo la segregación de la sensibilidad poética, obstaculizando de esa forma la posibilidad de un conocimiento total. Su propuesta aboga entonces por un nuevo encuadre del conocimiento filosófico, capaz de aunar las distintas facultades del sujeto dotándolo de una percepción íntegra del mundo exterior, tanto por vía intelectual como también por vía emocional.

6 Esta aseveración no desconoce que la postura de Ortega con respecto al Quijote también consolidó el aporte a cierta lectura filosófica capaz de sondear los sentidos de lo literario por fuera del valor erudito. De hecho, fue en las propias Meditaciones del Quijote donde Ortega definió a la filosofía como acto de amor intelectual contrapuesto a la mera crítica erudita: "La filosofía es idealmente lo contrario de la noticia, de la erudición. (...) Volver a ella en nuestra edad equivaldría a una regresión de la filología, como si la química tornara a la alquimia o la medicina a la magia. Poco a poco se van haciendo más raros los meros eruditos, y pronto asistiremos a la desaparición de los últimos mandarines" (1976: 21-22).

7 En esta línea el mismo Unamuno invita a leer su reescritura del Quijote como novela paradójica que repone la verdadera filosofía española, aquella que ni siquiera la erudición había logrado plasmar en sus obras históricas: “En una obra de burlas se condensó el fruto de nuestro heroísmo; en una obra de burlas se eternizó la pasajera grandeza de nuestra España; en una obra de burlas se cifra y compendia nuestra filosofía española, la única verdadera y hondamente tal; con una obra de burlas llegó el alma de nuestro pueblo, encarnada en este hombre, a los abismos del misterio de la vida. Y esa obra de burlas es la más triste historia que jamás se ha escrito; la más triste, sí, pero también la más consoladora para cuantos saben gustar en las lágrimas de la risa la redención de la miserable cordura a que la esclavitud de la vida presente nos condena" (1938: 214). 
$¿ \mathrm{O}$ es acaso que hemos tenido alguna forma de conocimiento peculiar y heterodoxo con respecto a las grandes formas clásicas del saber? Mientras Europa creaba los grandes sistemas filosóficos desde Descartes a Hegel [...], el español, salvo originalísimas excepciones individuales, se nutría de otros incógnitos, misteriosos manantiales del saber que nada tenían que ver con esta magnificencia teórica... (1986b: 89).

En este sentido Zambrano sostiene que la filosofía española emerge del fracaso, de "la aceptación realista resignada y al par esperanzada, del fracaso" (94), y que en esa línea "ni la Filosofía ni el Estado están basados en el fracaso humano como está la novela" (94), por lo cual "tenía que ser la novela para los españoles lo que la Filosofía para Europa" (94). Así, el Quijote surge tempranamente en el discurrir de Zambrano como libro-esfinge donde, a la manera unamuniana, puede hallarse la filosofía del pueblo español:

Es Cervantes quien nos presenta el fracaso del español, quien implacablemente nos pone de manifiesto aquella maravilla de voluntad coherente, clara, perfecta, que se ha quedado sin empleo y no hace sino estrellarse contra el muro de la nueva época (94).

Si el Quijote pudo cifrar la verdadera filosofía de un pueblo es porque ese pueblo se configuraba también a sí mismo como enigma a resolver. Tal como también había ocurrido en el caso de Unamuno, la obra de Zambrano logra conectar libro, nación y mito reconduciendo el enigma de uno a otro. Si el libro es cifra de España, lo es porque España misma se ha proyectado como enigma en sí, casi como pueblo-esfinge. Esto queda claro en "La crisis del racionalismo europeo", sección de Pensamiento y poesía en la vida española (de 1939) donde la autora afirma ya al respecto:

Pueblo rebelde, inadaptado, glorioso y despreciado, enigmático siempre, que se Ilama España. Su enigma nos presenta hoy un enigma universal, una interrogación sobre el porvenir. Su pasado está vivo por tanto, ya que en él laten las entrañas de este porvenir incierto y que tan desesperadamente esperamos (2015: 563).

Esta descripción de España anticipa tempranamente la que ya hemos evocado y que aparecería años después en Persona y democracia, lo cual demuestra en un arco de casi veinte años la persistencia metafórica de la Esfinge para la definición de España. Como la Esfinge, y como el Quijote, España guardaría en sí misma un enigma, una interrogación sobre el futuro cuya clave sólo podría hallarse en la íntima aceptación del pasado. Ante la crisis, la metáfora "viva" -en términos de Ricoeur- logra nominar y crear aquello que tan difícil resulta conocer. La nueva historia, tal como explica Zambrano, sólo se dará entonces por su unión con la poesía, superando la humillación a la que puede haberla sometido la soberbia filosófica:

Y el nuevo saber fecundo sólo lo será si brota de unas entrañas enamoradas. Y sólo así será todo lo que el saber tiene que ser: apaciguamiento y afán, satisfacción, confianzay comunicación efectiva de una verdad que nos haga de nuevo comunes, participantes; iguales y hermanos. Sólo así el mundo será de nuevo habitable (2015: 570).

En la estela anti-erudita, Zambrano parece reforzar la defensa de un nuevo saber que contrarreste las consecuencias histórico-políticas del afán positivista, imperial y excesivamente racionalista. Un nuevo saber y una nueva historia: su planteo, orientado a la superación de la tragedia, resuena en cercanía con la hipótesis unamuniana de descubrir la propia filosofía en el enigma vital que encierra esa Esfinge que es España, una patria cuya identidad podría revelarse a través de la exégesis de su libro fundacional, el Quijote. En este sentido, el ilustre hidalgo condecía claramente con el 
sujeto soñado por Zambrano en Filosofía y poesía (también de 1939), es decir, un sujeto capaz de sortear la historia trágica conjugando -como Unamuno y como don Quijote, cada uno a su manera- ambos planos de lo filosófico y lo poético:

La cosa del poeta no es jamás la cosa conceptual del pensamiento, sino la cosa complejísima y real, la cosa fantasmagórica y soñada, la inventada, la que hubo y la que no habrá jamás. Quiere la realidad, pero la realidad poética no es sólo la que hay, la que es; sino la que no es; abarca el ser y el no ser en admirable justicia caritativa... (2006: 22).

Este planteo no solo cimentaría prontamente las bases de la razón poética de Zambrano, sino que además vertebraría su propia lectura del personaje cervantino como metáfora viva. En "La mirada de Cervantes", 8 de 1948, Zambrano sostiene que toda cultura "deja ver la necesidad de imágenes que orienten el esfuerzo de ser hombre" (2001: 133). Esas imágenes "dirigen y hasta justifican, el hacer y el padecer que constituyen la historia de un pueblo" (133). Y afirma:

No parece dudoso que entre todas las figuras creadas por la literatura española sea la de Don Quijote la que alcance este rango en mayor grado en la conciencia española. Que sea también el símbolo aceptado universalmente lo confirma (133).

Ahora bien, la novela sería en opinión de la autora una deriva declinante del mito. Su ambigüedad constante -favorecida incluso por la presencia de Sancho, espejo inverso de la imagen "sagrada" del caballero-, estaría exigiendo una liberación. Don Quijote es ambiguo al haber sido consagrado como héroe sólo por medio del sacrificio que implica su tragedia: sometido a su heroísmo paradójico por una pesadilla ancestral, replica "el sacrificio total de España como realidad histórica" (136). Nunca estuvo el hidalgo más cerca del carácter de la Esfinge que en esta descripción: "Don Quijote enloquecido nos plantea el enigma de la libertad" (134). Ante las estrategias ya mencionadas de Unamuno y de Ortega, Zambrano parte de los postulados del escritor vasco pero sugiere finalmente ir más allá, casi a sus antípodas: propone hacer nacer una filosofía "de la necesidad de vivir fuera de la tragedia" (137). Esta es su discontinuidad, originada paradójicamente del legado trágico unamuniano. Una vez más aparece su idea del despertar quijotesco del sujeto ante una historia más humana, ya no trágica sino liberada de todas sus máscaras:

por la unión de la filosofía y de la poesía, nuestro Don Quijote encontrará liberación, la liberación de los encantamientos del mundo al mismo tiempo que de su locura: y con él todas las figuras nacidas de los sueños fantásticos de la esperanza (138).

\section{Hacia un despertar quijotesco: a modo de conclusión}

El enfoque de Zambrano con respecto al Quijote prosigue en esta vía y consigue con el tiempo su consolidación. Para 1965, dentro de El sueño creador, aparece una sección titulada "La novela: «Don Quijote». La obra de Proust". Allí la autora explica que tanto la novela como la tragedia tienen su centro en el protagonista: la diferencia radica en cómo cada género sitúa a su protagonista frente a sí mismo. Mientras el héroe trágico se precipita en su acción sin elegir, el personaje de la novela "se constituye en lo que pretende ser" (1986a: 78). A su juicio, los personajes de novela perciben la realidad como contrapartida del "soñarse despierto" (78). De ese modo, y tal como ocurriría con don Quijote, los héroes de novela "padecen y actualizan el sueño de la 
libertad" (78). Es de esta forma que en la filosofía de Zambrano el Quijote renueva su carácter de Esfinge ante la cual se conjura la historia sacrificial: el libro viene a encerrar dentro de sí mismo una enigmática verdad en torno a la liberación de la tragedia, a la posibilidad de hacer nacer una nueva conciencia y una historia humana. "La novela es la fatal contrapartida del racionalismo europeo clásico" (78) señala Zambrano y ubica el valor del Quijote en su veta anti-erudita, como nodo significativo del nuevo saber filosófico y poético a la vez. Zambrano logra entonces metabolizar la identificación libro / nación / mito presente ya en el legado anti-racionalista unamuniano: así su encuadre personal sobre el libro cervantino termina por fundarse en un discurrir metafórico que debe mucho a las Esfinges y quijotes de Unamuno. En "La ambigüedad de Cervantes" la autora se pregunta: “¿No puede acaso residir ahí, en la forma novelesca, algo muy sutil del secreto, sino el secreto?" (1965: 15). Es claro que el asedio de ese secreto pudo en parte realizarlo Zambrano apelando al circuito metafórico que la había precedido, esa operación recurrente que logró ver en el Quijote un "signo totémico" (15) capaz de cifrar, cual Esfinge, una verdad crucial y poética sobre España y su íntima filosofía. Rodeada por los monumentos fúnebres del proyecto imperial, Zambrano afirmó de manera infatigable que el reinado del racionalismo europeo había descartado todo aquello que no le pertenecía. Entre sus estrategias de redención pudo entonces constituir una hermenéutica del Quijote-clave para la comprensión de su razón poética-, la cual debía parte de su entramado metafórico al legado unamuniano, del cual se distinguiría sin embargo al privilegiar una historia por fuera de lo trágico. A partir de su mirada, entonces, la nueva historia exigiría un saber ya no erudito sino poético, o mejor aún, un despertar humano cuyo quijotismo le permitiera descifrar finalmente el enigma de un futuro posible. 


\section{Dibliografía}

» Borges, J. L. (2001). Arte poética (seis conferencias pronunciadas en inglés en la Universidad de Harvard, 1967-1968). Barcelona: Crítica.

"Close, A. (2005). La concepción romántica del Quijote. Barcelona: Crítica.

» Macías Villalobos, C. (2012). "Algunas consideraciones sobre el simbolismo de la Esfinge”. Mirabilia, 15, 250-287.

"Ferraro, C. L. (1999). "María Zambrano, intérprete de Miguel de Unamuno". Cuadernos de la Cátedra Miguel de Unamuno, 34, 13-28.

" Ortega y Gasset, J. (1976). Meditaciones del Quijote. Ideas sobre la Novela. Madrid: Espasa Calpe.

» Ricoeur, P. (1977). La metáfora viva. Buenos Aires: Magápolis.

"Sánchez-Gey Venegas, J. (2002). "La mirada zambraniana sobre Unamuno". Cuaderno Gris, 6, 197-204.

» Soto Carrasco, D. (2013). "La construcción de una gnosis española. De Menéndez Pelayo a María Zambrano”. En: Rivera García A. y Villacañas J. L. (coord.), Gonzalo Díaz y el archivo de la filosofía española. Murcia: Universidad de Murcia, 211-238.

» Trapanese, E. (2010). “El Caballero de la Locura y su ambigüedad: Don Quijote entre Unamuno y Zambrano”. Bajo Palabra. Revista de Filosofía, II Época, N5, 349-366.

»Unamuno, M. de (1938). Vida de don Quijote y Sancho. Buenos Aires: Espasa-Calpe.

"Unamuno, M. de (1952). “Don Marcelino y la Esfinge”. En: Obras completas (tomo V). Madrid: Afrodisio Aguado, 402-405.

» Unamuno, M. de (1952). “Eruditos, ia la Esfinge!”. En: Obras completas (tomo V). Madrid: Afrodisio Aguado, 804-807.

"Zambrano, M. (1965). “La ambigüedad de Cervantes”. En: Zambrano, M., España, sueño y verdad. Barcelona: Edhasa, 15-31.

"Zambrano, M. (1986a). “La novela: "Don Quijote». La obra de Proust”. En: Zambrano, M., El sueño creador. Madrid: Turner, 78-87.

»Zambrano, M. (1986b). “La Reforma del Entendimiento español”. En: Zambrano, M., Senderos. Los intelectuales en el drama de España. La tumba de Antígona. Barcelona: Anthropos, 87-104.

»Zambrano, M. (1988). Persona y democracia. Barcelona: Anthropos.

"Zambrano, M. (2001). "La mirada de Cervantes". Aurora: papeles del Seminario María Zambrano, núm. 3, 133-8. En: https://raco.cat/index.php/Aurora/article/ view/144897; obtenido el 23/02/2021.

"Zambrano, M. (2006). Filosofía y poesía. México: Fondo de Cultura Económica.

"Zambrano, M. (2015). Pensamiento y poesía en la vida española. En: Obras completas (tomo I). Barcelona: Galaxia Gutenberg, 517-658.

"Zambrano, M. (2017). Unamuno. Gómez Blesa M. (introducción y notas). Barcelona: Penguin Random House / Debate. Kindle e-book. 
